\title{
Understanding and optimising the social impact of venture capital: Three lessons from Ghana
}

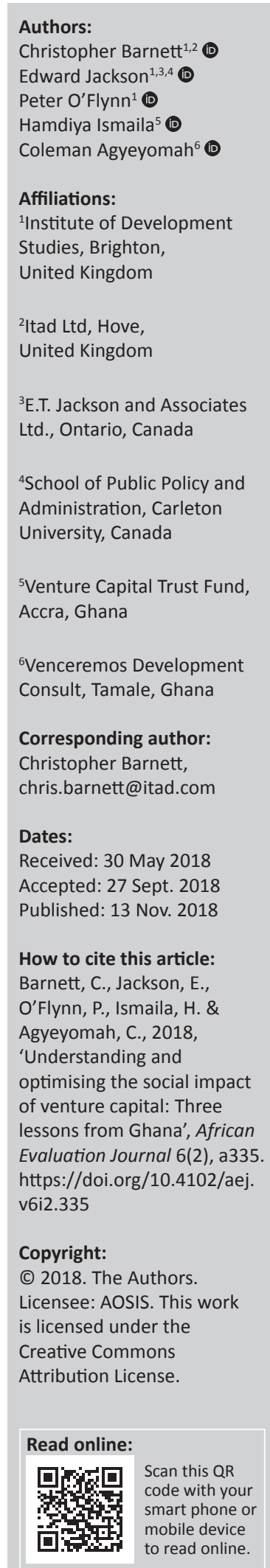

Background: Mobilising investment for sustainable development is a priority for many African governments and their international allies. There are many claims about the social impact of investments in small and growing businesses, and yet these mostly focus on good news stories or a narrow set of metrics (jobs created, tax revenue, etc.). There are relatively few studies that consider the diversity of social impacts, particularly in an African context.

Objectives: The aim of this research was to work collaboratively with investors in Ghana to better understand social change and contribute to their own work on improved performance and reporting.

Method: Using a theory-based examination of social impacts, the research purposively selected a subset of 13 investments from the Venture Capital Trust Fund (VCTF) in Ghana. Theories of change were used to explore the available documentation, triangulated with insights from fund managers, entrepreneurs, senior managers and, where possible, employees. The findings were validated with VCTF staff.

Results: While the research demonstrated the usefulness of a theory-based approach, it found it helpful to develop a smaller set of typologies to capture different impact pathways - a more efficient way to assess and report on social returns. In particular, the research highlights how commonly used metrics like job creation undervalue the social impact of some types of investment. Other lessons also included the value of rural businesses (not typically favoured by venture capitalists) and the potential to further extend impacts to lower income groups, but that this required real intent and leadership on the part of investors and entrepreneurs.

Conclusion: We conclude that further research is merited on two fronts. Firstly, research into the scale of the small and medium enterprises and the associated investment required to support the operating costs to really manage, improve, monitor and evaluate social impact. And secondly, further field testing of different evaluation techniques to help stakeholders better understand and improve the social benefits of venture capital.

\section{Introduction}

Mobilising venture capital - usually in the form of the placement of funds in small and growing businesses - to fuel sustainable development is a priority for many African governments and their international allies. Yet, most assessments of social impact tend to focus on a narrow set of measures, particularly the creation of direct and indirect jobs by the small and medium-sized enterprises $\left(\mathrm{SMEs}^{1}\right)$ benefiting from an investment. Through a collaborative, theory-based examination of social impacts, the aim of this research was to better understand and document the social impacts of the Venture Capital Trust Fund's (VCTF's) investments and its affiliated funds in Ghana and, in doing so, work with the Trust Fund to contribute to improved performance and better reporting of social impacts. The study also offers broader insights into the use of theories of change in evaluating social change, particularly below the firm level, where there tends to be limited evidence of the impact on African households. ${ }^{2}$

Three lessons emerged from the study of 13 VCTF investments in SMEs. Firstly, different types of business models, applied in a range of sectors, produce a variety of social impacts. This research found it useful to classify the SMEs benefiting from an investment as either 'job creators', 'service providers' or 'market makers' (terms we describe later on). Secondly, the job creating effects and

1.For simplicity, we use the term SME or enterprise throughout this article. This is a shorthand for an "SME benefiting from a venture capital investment' (investee) as opposed to the one undertaking the investment (the investor). On a few occasions, we revert to the capital investment' (investee) as opposed to the one undertaking the investment (the in
term 'company' as this refers to a registered name or a specific legal status in Ghana.

2.A recent publication highlights the real, but largely unexplored, potential of designating the household as the prime unit of analysis for evaluating the results of impact investments (Jackson \& Harji 2017). 
associated social benefits of rural businesses, which are typically not favoured by venture capitalists, can be particularly significant for the communities and households of their workers and suppliers. And thirdly, it is possible to deliberately strengthen the social impacts of an enterprise over time, but this requires intentionality and focus on the part of investors and entrepreneurs.

We conclude this article by reiterating the important role of capital investment in achieving the Sustainable Development Goals (SDGs). While the VCTF may be viewed as an untypical investor, it co-invests through the same funds as private investors and shares similar traits to Development Finance Institutions. ${ }^{3}$ As such, we suggest that this study has broader applicability. In this article, we argue that the nature and significance of the social impact by SMEs is diverse and we caution against a potential bias in reporting impact metrics (such as job creation ${ }^{4}$ - especially as this may undervalue important social returns. We argue that such social impacts need to be understood through different pathways of change and that a typology can usefully navigate this diversity in an efficient and manageable manner. To develop this further, we suggest that research into a larger and more diverse sample of venture investments in Ghana and elsewhere on the continent is merited. One question worthy of investigation centres on the extent to which the scale of SMEs or the scale of the fund investing in them enables larger and longerlasting social impacts. Another line of future inquiry involves testing different combinations of evaluation techniques that can help stakeholders better understand and improve the social benefits of venture capital. To this end, the study underscores the insights that can be gained through collaborative inquiry among investors, investees and evaluation specialists, learning what works for future investment to achieve development effects - and under which circumstances this is most effective.

\section{Venture capital and the sustainable development goals in Ghana}

In recent years, there has been a growing recognition of the need to mobilise 'trillions not billions' to achieve the SDGs with the unmet investment need in developing countries estimated to be around $\$ 2.5$ trillion per year (UNCTAD 2017:125; IFC \& McKinsey 2010). Venture capital involves the placement of equity or quasi-equity investments aimed at enabling SMEs (especially start-ups) to flourish. These investments are done through a combination of funds from governments, institutional investors and high net worth individuals. Often carried out by private interests with their

3.Development Finance Institutions are banks or subsidiaries that are usually majority-owned by national governments. They are set up to operate semiautonomously and invest in the private sector to achieve financial and purposedriven returns.

4.We use 'direct job creation' as an example of potential underreporting of socia return throughout this article, as it is a commonly used metric (e.g. MacGillivray et al. 2017). what we highlight in this article is that for some investments it can be relatively low. This is not necessarily because the investment underperformed in terms of social impact, but rather it was not the primary social purpose of the enterprise (which impact, but rather it was not the primary social purpo
could be indirect jobs created, public benefits, etc.). own funds, with little regard for its social or development benefits, this field of practice has typically operated separately from the broader, more publicly oriented field of development. With the onset of Agenda 2030 (UN 2015) however, there is growing interest in finding ways of effectively mobilising, blending and deploying private capital for sustainable development. It is becoming more widely recognised that new forms of capital beyond aid and taxes must be raised and targeted if there is to be any chance of achieving the ambitious SDGs (Lindenberg \& Pöll 2015). This in turn has sparked interest in examining the social, or development, impact of the mainstream venture capital industry (e.g. UN PRI 2017). Typically, the focus for such investments is on their contribution to employment, growth and taxes. Through such outcomes, venture investments in SMEs can make a direct contribution to SDG 8, for example, which is concerned with promoting 'sustained, inclusive and sustainable economic growth, full and productive employment and decent work for all' ${ }^{5}$

A major barrier to the rapid development of the SME sector is access to finance. Evidence has shown a shortage of both debt and equity financing in countries where poverty is greatest. The case of Ghana is instructive in this regard: from 1994 to 2004, only two commercial venture capital funds are said to have been established in Ghana (Mensah 2004). ${ }^{6}$ For nearly 15 years, the VCTF has been raising and blending both public and private capital across Ghana through a series of sub-funds (which are independently managed) to finance the growth of SMEs. Since its inception in 2004, the Trust Fund has used this approach to mobilise and deploy capital in a wide range of sectors, including food, agri-businesses, energy, financial services, real estate, health care and education. At the same time, the VCTF has also played an animating role in organising networking meetings, educational events, policy seminars and research on venture financing, angel investing and impact investing.

Still today, the current investment portfolio of the VCTF continues in many ways to be shaped by the original conditions of the 2004 Act. The Venture Capital Trust Fund Act (Act 680) states that the VCTF is to

Provide financial resources for the development and promotion of venture capital financing for SMEs in Ghana by: (1) Providing financing to eligible Venture Capital Finance Companies to support SMEs; and (2) The provision of monies to support other activities and programs for the promotion of venture capital financing. (GOG 2004)

Under this legislation, SME is characterised as an industry, project, undertaking or economic activity whose total asset base, excluding land and buildings, does not exceed the Ghanaian cedi equivalent of $\$ 1$ million in value. The investments may be projects that are either start-ups or

5.https://sustainabledevelopment.un.org/sdgs

6.In 1991, USAID and CDC sponsored the formation of a venture capital fund, made up of a non-bank finance institution (Ghana Venture Capital Fund) and a management company (Venture Fund Management Company). Subsequently, Fidelity Discount House and FMO (the Netherlands) set up the Fidelity Equity Fund. 
enterprises in their growth or expansion stages. Generally, the Trust Fund is available to all sectors of the economy except businesses selling direct imports. Priority is nevertheless given to certain sectors of the economy, in line with the Government's economic growth policies and objectives. Currently, priority sectors include information and communication technologies (ICTs), agriculture, education, pharmaceuticals, housing and energy.

The promotion of 'social impact' per se was not however the prime purpose of the VCTF's investments. Indeed, at the time of the Fund's inception in 2004, venture capital was largely unknown and mostly an unused financial instrument, especially among the SME sector in Ghana, and the availability of deals was low. Since then, however, through its various activities, the Trust Fund has become interested in assessing the social benefits of its own investments in order to report more fully to government. ${ }^{7}$

Part of this has been the result of engagement by the Trust Fund in impact investing. In 2013, with a grant from the Rockefeller Foundation, the VCTF established a Centre for Impact Investing in the Business School of the Ghana Institute of Management and Public Administration, an Accra-based university. And in 2015-2016, also with Rockefeller Foundation support, the Trust Fund worked with a variety of partners to develop and test modules for an executive training programme in evaluating impact investment programmes and deals. ${ }^{8}$ In parallel, the General Manager of the Trust Fund animated a small group of women 'angel investors' ${ }^{\prime}$ to begin identifying and making initial investments in women-owned SMEs. All of these activities highlighted the social dimensions of the Trust Fund's holdings and informed its interest in participating in the research reported on here.

\section{Background to the study}

Based on a collaboration between the Centre for Development Impact $^{10}$ (CDI) and the VCTF, we examined 13 SMEs in Ghana that benefited from the Fund's investment. We used these example SMEs to determine, post-investment, the nature and extent of their social impact on their employees, suppliers and communities. The research is based on a series

\footnotetext{
7.Venture Capital Trust Fund is not a state enterprise, but reports to the Government of Ghana. It was established to promote the development of venture capital financing in Ghana and so has a broader objective. Importantly, while funding is from the government, the Trust Fund does not invest directly into SMEs; rather, the Fund leverages its funding with the private sector to create a pool of funds to invest in SMEs by private fund managers.

8.http://www.evaluatingimpactinvesting.org/training/ghana-april-2016-2/In Ghana, the partners included the VCTF, the Business School at the Ghana Institute of Management and Public Administration and the Institute for Policy Alternatives, and in South Africa, the key partners were the CLEAR Centre for Anglophone Africa at the University of the Witwatersrand and the consulting firm Greater Capital. With support from the Rockefeller Foundation, and later the Internationa Development Research Centre, in 2015-2016, the partners developed and piloted curriculum modules for the course, attracting local fund managers, foundation staff, donor agency officials, NGO personnel and university faculty.

9.Angel investing is used here to refer to high net worth individuals who invest and mentor start-up enterprises. With VCTF support, individual 'angels' came together to form an Angel Network, which in this case were made up of only individual women investors.

10.The Centre for Development Impact (CDI) is a partnership between the consulting firm Itad, the Institute of Development Studies and the University of East Anglia.
}

of qualitative case studies of SMEs, reviewing their theories of change from investment through to job creation and wider social impacts. Field visits to the SMEs were undertaken in December 2016, with on-site interviews conducted with the chief executives of the sampled firms as well as with select employees and suppliers. The enterprises range from food processing and castor oil production to rural finance, pension services, schooling, DNA testing and cancer medical care.

The aim of the study was to work with the VCTF to better understand and document the social impacts of the Trust Fund's investments and its affiliated funds ${ }^{11}$ and, in doing so, to contribute to improved performance and better reporting of the social impacts. The sampled SMEs were purposively selected using six criteria: (1) investments that were likely to have some form of social impact (or best suited for learning about social impact), (2) investments placed across a range of sectors (to learn about possible cross-sectoral differences in measuring social impact), (3) investments located in a variety of regions (Volta, Ashanti, Brong Ahafo, and not just Greater Accra), (4) investments that were spread across the various sub-funds (as VCTF co-invests through a number of different sub-funds), (5) investments drawn from the historical portfolio to redress regional or sectoral imbalances (e.g. the loan portfolio investments in the Northern Region of Ghana) and, finally, (6) investments that could be studied efficiently given time constraints, availability and the upcoming national elections. The final selection of sampled SMEs is listed in Table 1.

The inclusion of the four northern enterprises was motivated by three factors. Firstly, the three northernmost regions of Ghana continue to constitute the poorest part of the country, a situation that, despite many development interventions, has persisted for more than half a century. Secondly, the economy of the north continues to be driven by and reliant on agriculture. Thus, businesses that are engaged in various value chains in this sector are of prime public policy interest. Thirdly, a decade ago, VCTF itself delivered a government loan programme to a set of northern agricultural businesses and it was interested in assessing their progress and current status since then.

As the research could not focus on all market segments, because of time constraints and the availability of key stakeholders (fund managers, CEOs, senior managers, etc.), the decision was taken to focus on the most likely areas of social impact for the portfolio, that being in agriculture and agro processing, education, health care and financial service provision. Table 2 compares the selection of investments against the 2016 VCTF portfolio by sector. It shows that our selected investments were broadly in keeping with the major sectoral themes of the VCTF (particularly education, health care and financial services), although our sample overrepresents agriculture and agro processing and underrepresents other types of investment.

11.This was a short, qualitative study and relies on self-reported attribution (people's own contribution claims) to highlight issues for further research. The study does not attempt to rigorously attribute impact to the investments. 
TABLE 1: Selected investments from the Venture Capital Trust Fund portfolio.

\begin{tabular}{|c|c|c|c|c|c|c|}
\hline Number & Company name & Region & Sector & Instrument & Status & Fund \\
\hline 1 & African University College of Communication & Greater Accra & Education & Equity & Operational & Activity Venture Finance Company \\
\hline 2 & Axis Pensions Trust & Greater Accra & Financial service & Equity & Exited & Ebankese Venture Finance Company \\
\hline 3 & Caltech Ventures Limited & Volta & Agro processing & Equity & Exited & Gold Venture Finance Company \\
\hline 4 & EKA Processing & Brong Ahafo & Agro processing & Equity & Operational & Activity Venture Finance Company \\
\hline 5 & Rising Sun Montessori School & Greater Accra & Education & Equity & Operational & Ebankese Venture Finance Company \\
\hline 6 & Scientellect Company Ltd & Greater Accra & Health care & Equity & Operational & Bedrock Venture Finance Company \\
\hline 8 & Vester Oil Mills & Ashanti & Agro processing & Equity & Exited & Activity Venture Finance Company \\
\hline 9 & Wenchi Rural Bank & Brong Ahafo & Banking & Equity & Operational & Ebankese venture finance company \\
\hline 10 & Heritage Seeds Company & Northern & Agro processing & Loan & Exited & Special Purpose \\
\hline 11 & Savannah Farmers Marketing Company & Northern & Agro processing & Loan & Exited & Special Purpose \\
\hline 12 & Behisung Farms Limited & Northern & Agro processing & Loan & Exited & Special Purpose \\
\hline 13 & Dabbu Farms Limited & Northern & Agro processing & Loan & Exited & Special Purpose \\
\hline
\end{tabular}

Source: Authors' own work based on Venture Capital Trust Fund (VCTF) records

TABLE 2: Sectoral distribution of selected small and medium enterprises investments compared with the full Venture Capital Trust Fund portfolio.

\begin{tabular}{lcc}
\hline Sector & $\begin{array}{c}\text { Selection of } \\
\text { investments (\%) }\end{array}$ & $\begin{array}{c}\text { Total VCTF sectoral } \\
\text { distribution (\%) }\end{array}$ \\
\hline Agriculture + agro processing & 53.85 & 22.20 \\
Education & 15.38 & 16.70 \\
Health care & 15.38 & 13.90 \\
Financial services (including banking) & 15.38 & 11.10 \\
Other & 0.00 & 36.10 \\
\hline
\end{tabular}

Source: Authors' own work based on Venture Capital Trust Fund (VCTF) records

Our selection of investments was drawn mostly from the Greater Accra region, followed by the Northern Region, Brong Ahafo, Volta and Ashanti regions. The distribution of our sample again mostly mirrors the current VCTF portfolio, although it differs in two main ways: Firstly, the current VCTF portfolio is dominated by Greater Accra investments, and this is less dominant in our sample. Secondly, we included Northern Region investments, which better reflect the historic portfolio as there are currently no VCTF investments in this area. Both reflect a deliberate aim of the study to capture insights from other regions, so as to help contribute to broader learning on the range of social impacts.

For each selected investment, the team developed investment profiles, documenting the SME's investment thesis, instruments, terms and conditions, investment performance, job creation (direct and indirect), wider social impacts, and current reporting and measurement approaches. These profiles were first completed on the basis of a document review supplemented by calls and initial discussions with staff of the VCTF. Field visits to the SMEs, and key-person interviews with chief executives, staff and employees were used to supplement and triangulate findings. A cross-case analysis was then undertaken to draw out themes, similarities and differences, and the initial findings verified during a de-briefing session with VCTF staff in Accra. One of the purposes of the study was to work collaboratively with VCTF staff in an appreciative enquiry of social change (where it could be identified), and thus it is acknowledged that the study is limited in that it underplays negative or unexpected effects. The rest of this article focuses on the main findings of the study.

\section{Typologies of investments}

The VCTF portfolio of investments is diverse. Portfolio diversification has inherent advantages through spreading unsystematic risk and is a major part of portfolio theory across the investment space. Nevertheless, whereas there are internationally accepted accounting standards for financial return, assessing the social impact of investments is a relatively fledgling undertaking because of the 'coining' of impact investing around 2007 and (alongside that) the intentionality of impact investors to measure their social impact (Flynn \& Young 2016; Flynn, Young \& Barnett 2015; So $\mathcal{E}$ Staskevicius 2015). The emergence of certification bodies and standardised metrics (e.g. the Impact Reporting and Investment Standards [IRIS], Global Impact Investing Reporting Standards [GIIRS], Sustainability Accounting Standards Board [SASB] and Benefit Corporations [B-Corps]) offers one pathway but is not without its own challenges. For example, the IRIS catalogue provides over 500 possible metrics. For a relatively small investor like the Trust Fund, with limited resources available for assessing social impact, it is very demanding to distil and examine even the 'vital few' indicators when the investment portfolio is so varied.

One way to address this challenge is to map out a theory of change: an explicit logic chain explaining how the investment is expected to improve SME performance, direct and indirect job creation, tax revenue and the likely social effects on employees, households and society more broadly. Based on this thesis, the argument goes, it is then possible to identify changes that are common to all investments, as well as distinguish more immediate effects that are amenable to metrics from those of harder-to-measure social impacts (e.g. Figure 1).

While theories of change provide a useful starting point, this study found that this alone was insufficient to understand and explain the dynamics and results across the portfolio as a whole. When we explored the theories of change with enterprise managers and staff, then commonly assumed metrics (like job creation) were not equally applicable to all investments, with some SMEs creating relatively few jobs but having a social impact in other important ways. As such, our 


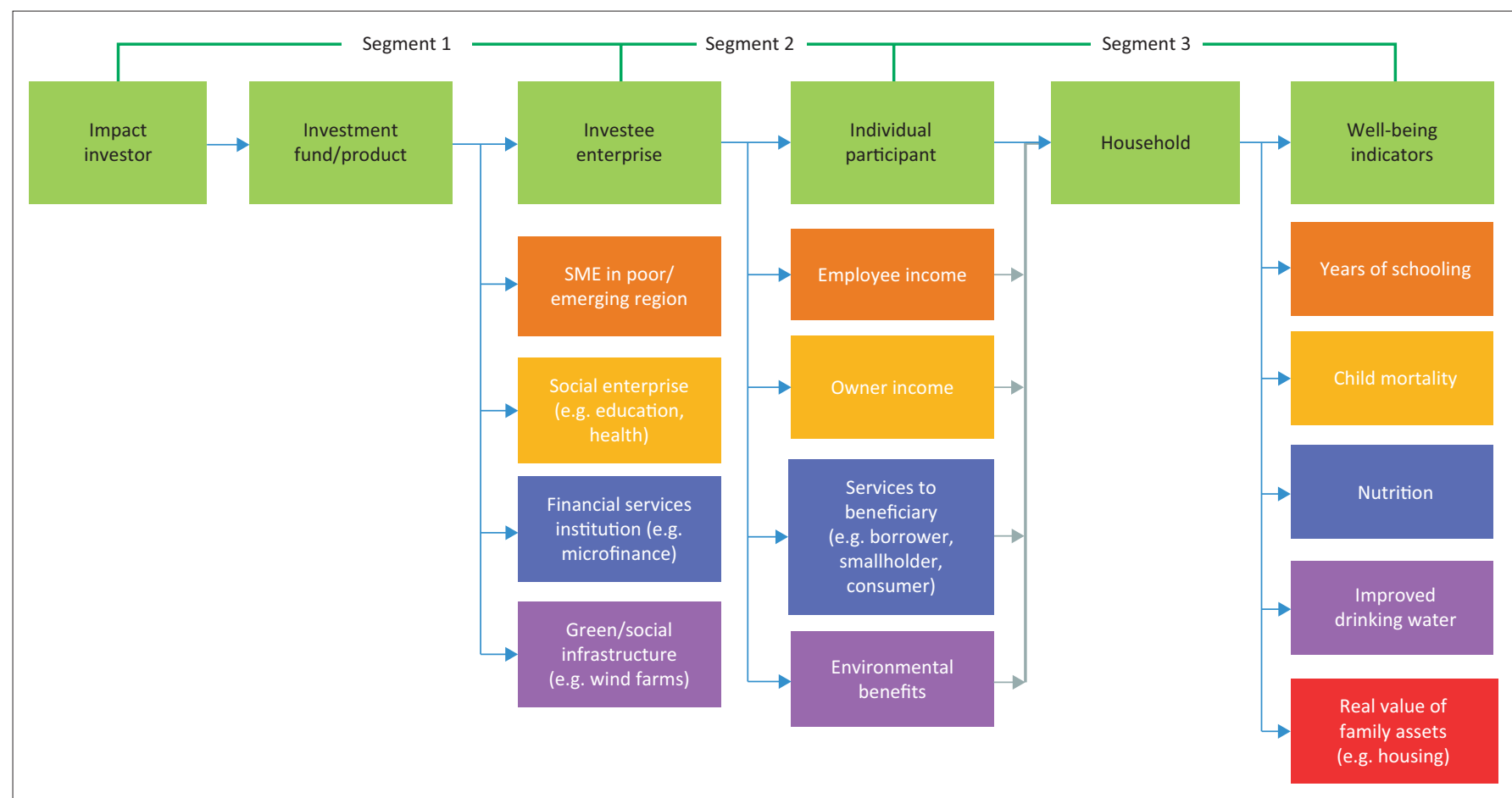

Source: Jackson, E.T. \& Harji, K., 2016, Module 22 - Household Impacts, from the Syllabus for Executive Course - Evaluating Impact Investing in Africa, E.T. Jackson and Associates Ltd, Ontario, Canada. FIGURE 1: A schematic of an investment-level theory of change.

study partly validates the literature that says theories of change are a useful device for placing standardised metrics (e.g. IRIS, GIIRS and SASB) within an explicit logic that explains social impact (Jackson 2013), although our study goes further and argues for the need to develop typologies of expected change that take account of very different impact pathways. Based on a matrix of social change indicators for each investment, we were able to identify a number of different types that were verified with staff of the VCTF. To this end, we made use of three typologies for classifying the portfolio in terms of social change by determining whether they are primarily 'job creators', 'service providers' or 'market makers'. The first lesson of our research, therefore, is that different types of SME business model, applied in a range of different sectors, produce a variety of social impacts.

\section{Job creators: Creating social impact through work}

Whereas the majority of SMEs in the sample portfolio generated relatively low numbers of direct jobs, a few investments had created large numbers of indirect jobs. ${ }^{12}$ Indeed, for most of the VCTF investments examined, direct job creation was surprisingly low compared with the size of the equity investment, often being in the range of around 20-70 employees ${ }^{13}$ for considerable equity finance (such as a combined equity and debt investment of GHф1300 000.00 for Wenchi Rural Bank, and as small as GHф150 000 for

12.This is only a small sample of investments, and so this observation is relative to other investments in the sample, rather than being benchmarked against a national or international standard of jobs created (or 'jobs created per dollar invested'). There was a tangible difference in magnitude across our sample of invested'). There was a tangible difference in magnitude across our sample of
investments: direct jobs ranged from 10 to 170 employees, whereas indirect jobs investments: direct jobs ranged from
ranged from 220 to over 1000 jobs.

13.Note: This is a proxy based on total employment figures rather than directly attributed to the investment.

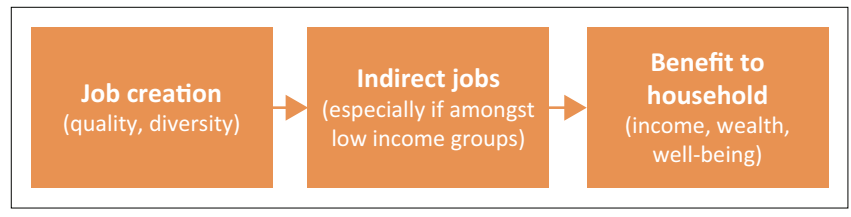

Source: Barnett, C., O'Flynn, P., Ismaila, H., Agyeyomah, C. \& Jackson, E., 2016, Understanding and optimizing the social impact of venture capital: Three lessons from Ghana, Draft Manuscript, unpublished, Centre for Development Impact, Institute of Development Manuscript, unpubies, Brighton

FIGURE 2: The social impact pathway of job creator small and medium enterprises.

EKA processing). Nonetheless, for a handful of investments, the indirect job creation was found to be significant, ${ }^{14}$ running into hundreds and sometimes thousands of jobs (as per impact pathway in Figure 2). In several cases, such job creation was clearly attributable to the investment because the equity injection demonstrably helped support the development of their respective supply chains - as discussed in the examples below. Common to all these enterprises was that they operated in rural parts of Ghana. In such locations, employment by even one family member can have a significantly (and disproportionally) positive impact on a household and their extended relations. For example, in one interview, ${ }^{15}$ Priscilla (an employee of Wenchi Rural Finance) explained how having a job had an impact on the purchasing power of her entire household, including being able to cover various consumables, medical bills and school fees, support a sister in doing an academic degree elsewhere, as well as procure other consumables.

14.Significance is used here in terms of the quantity of indirect jobs created, compared with figures provided for direct job creation. It was however beyond the scope of this study to explore the nature of indirect jobs, as clearly not all jobs are equal and some may offer greater social impact by providing stability (e.g. to market their produce), with others the converse.

15.The name has been changed to protect the anonymity of the respondent. 
In another example, EKA Processing financed by VCTF through the Activity Venture Finance Company sub-fund and based in Sunyani has sought to exert an intentional effect on indirect job creation through its out-grower value chain. EKA is a producer of fresh and dried chilli pepper, ginger and other produce from local farmers. While there are only 10 permanent employees, the SME has direct relationships with approximately 1000 out-growers in the local area. This includes 500 ginger growers, approximately 360 farmers who grow chilli peppers, and 100 for aubergines. EKA supports these individuals, by providing inputs and advice and offering a guaranteed price.

Similarly, Vester Oil Mills (also funded under the Activity Venture Finance Company) is a medium-scale vegetable oil processing enterprise, providing value-added agro processing oils from soya and palm kernels. There are 70 employees, mostly based at the central plant, all of whom are full-time, with $20 \%$ of the workforce being female. While no data were available on the exact number of out-growers, it is estimated to run into many thousands. For instance, Vester Oil Mills works with a number of associations, including Savannah Farmers Marketing Company (which is a nongovernmental organisation [NGO] association with 15000 soya out-growers). And, in one community alone, the managing director noted, there are more than 1000 outgrowers. Vester Oil Mills contributes to the sustainability of these indirect jobs, by providing information on tractor servicing, informing individuals about the seed varieties and offering financial assistance (loans and guarantees to certain out-growers to enable the purchase of farming inputs, which are paid back later).

Within the study sample, it is not only food-processing plants that support large numbers of indirect jobs but also other enterprises, notably Caltech Ventures Ltd (an ethanol producing factory located in a rural area of Volta region) and Wenchi Rural Bank (a rural finance loan provider). While it was beyond the scope of this study to measure these economic effects, these four investments stood apart from the others in the sample in terms of job creation. It was evident that these four investments made a clear contribution to many thousands of additional jobs, whereas for the other investments, their social impact was less obvious about employment with numbers being very low in comparison (often just 10s of jobs per enterprise and few directly attributable indirect jobs). The nature of their contribution is explored in two further pathways to social change.

\section{Service providers: Private enterprise providing public services}

Secondly, there was a subset of enterprises whose core business is to provide a service with a direct social benefit, such as education or health care - services which are traditionally provided by the public or non-governmental sectors (see Figure 3). In our sample, the social benefits of these enterprises (such as the improved learning outcomes of school age children) were found to be accrued generally by

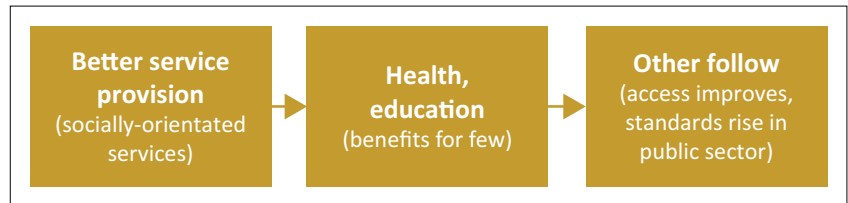

Source: Barnett, C., O'Flynn, P., Ismaila, H., Agyeyomah, C. \& Jackson, E., 2016, Understanding and optimizing the social impact of venture capital: Three lessons from Ghana, Draft Manuscript, unpublished, Centre for Development Impact, Institute of Development Studies, Brighton

FIGURE 3: The social impact pathway of better services providers.

the well-off - that is, a middle or elite class of customers that could afford such services. However, particularly in the health and education sectors, several SMEs claimed to be setting higher standards that in time would improve the overall standards in the public sector for everyone (e.g. Rising Sun, Sweden Ghana Medical Centre, Scientellect). This claim is difficult to assess and verify, as it would need to be measured across a longer period of time and more systemwide, something not covered by this study. ${ }^{16}$

The Rising Sun Montessori School - a VCTF investment through the Ebankese Venture Finance Company - runs a group of private schools for 1200 students, providing care and education from crèche or pre-school, through to primary and junior high school. Rising Sun employs 170 staff across three schools. The number of outsourced services is limited, and there is a limited supply chain, and thus probably a small effect on indirect jobs. Using an adaptation of the Montessori approach, the school's social effect is primarily focused on the provision of quality (and holistic) education. ${ }^{17}$ The school targets parents who are of lower-middle income, with both or one parent working and living in the local area and looking for a school that is nearby. There are many schools in the area, but interviewees argued that many parents see Rising Sun as offering a higher standard and are therefore attracted to it. The school also offers a strong emphasis on culture and values, including teaching subjects in Ghanaian languages, on Ghanaian culture, social skills (e.g. how to make polite requests or to refuse something), the Chinese language and the culture of its people, plus a day for African culture. Rising Sun leaders find it difficult to fully quantify their social impacts and make the case that doing so can only ultimately be realised over the longer term (by assessing the potentially improved life opportunities of students after leaving Rising Sun and entering secondary school, higher education and the workplace).

In another example, Scientellect is a fertility treatment centre and DNA laboratory and testing facility based in the City of Hope hospital in Accra. The original objective of the business was to set up a laboratory to help diagnose sickle cell disease (for which an estimated $15 \%-20 \%$ of Ghanaians

16.This section focuses on the positive claim of individual enterprises, but clearly investments of this nature can have the opposite effect as public systems get less funding, less qualified staff because of competition, and as a result standards in public systems decline. Rather this section is more illustrative of the wider point in public systems decline. Rather this section is more illustrative of the wider point in this article about the need to consider investments by the differences (and
assumptions) in their pathways to change.

17.The Montessori method is a child-centred educational approach that views the child as one who is naturally eager for knowledge and capable of initiating learning. It takes a holistic approach to education and focuses on moral, behavioural, emotional and intellectual development (see https://montessori-ami.org/). 
carry the damaged gene). There are many mothers who give birth to children with the disease, which in turn can have a significant impact on families. The goal was to provide laboratory services to assist with the pre-natal diagnosis and management. In the end, there were not enough cases for the business to be viable, and subsequently Scientellect diversified into infertility treatment, which currently provides about $85 \%-90 \%$ of its revenue. While, like Rising Sun, the social effects of the centre are difficult to quantify, it has since 2014 provided fertility services to over 1000 patients. The benefits of these services are likely to contribute (in a small way) to improvements in the quality of health provision in Ghana and for those patients beyond their time at the clinic.

In both these SME cases, and in a few others in the sample (e.g. Sweden Ghana Medical Centre and African University College of Communication), the very purpose of the enterprise is to provide a service that generates a social and (likely) public benefit such as better health or education. The assumed positive benefits are difficult to capture at the firm level, as they are mostly realised years later (e.g. improved quality of life for school alumni). This contrasts with the previous examples of EKA or Vester Oil Mills, where the social impact was not about the particular goods or service being produced by these companies (whether oil, processed chillies, etc.), but rather their contribution to indirect job creation and its effects on poor rural households and communities.

\section{Market makers: Early adopters demonstrating social impact}

Finally, there were enterprises that fitted neither category. Thus, we found it useful to classify a subset of VCTF-invested enterprises that were noticeably different than what previously existed in their respective markets or sectors. These firms we labelled early adopters or market creators (as per the pathway set out in Figure 4). In these examples, the numbers of direct or indirect jobs created were unexceptional. Yet from interviews with chief executives, fund managers and staff, these companies appeared to be offering groundbreaking innovations that in time could contribute to a shift in the wider market system. For example, the Sweden Ghana Medical Centre (SGMC) is the first and only provider of cancer care in Ghana, providing a valuable alternative to patients otherwise obliged to seek treatment in other countries as far away as India or Turkey. The focus of this investment and others was primarily on market formation,

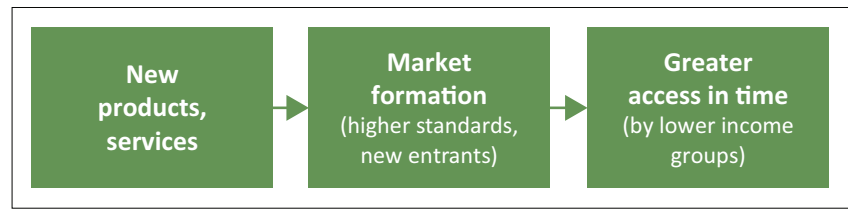

Source: Barnett, C., O’Flynn, P., Ismaila, H., Agyeyomah, C. \& Jackson, E., 2016, Understanding and optimizing the social impact of venture capital: Three lessons from Ghana, Draft Manuscript, unpublished, Centre for Development Impact, Institute of Development Studies, Brighton

FIGURE 4: The social impact pathway of market makers. which over time aimed to establish a broader ecosystem of suppliers and complementary services. Again though, the social effect is difficult to establish and requires detailed study using more than a metrics-based approach alone.

For instance, SGMC is the only cancer treatment centre in Ghana. Its main competitors are non-medical alternatives in Ghana (e.g. when patients choose the church and herbalists and leave the medical treatment of their cancer until it is too late), or 'health tourism', where people travel abroad to seek treatment. There are nine centres for radiotherapy in Nigeria (although these are said to not always be operational), and Ghanaians presently travel to other cancer treatment centres as far away as Morocco, Egypt, Turkey and India.

The SGMC offers a premier service for the elite of Ghana. The focus is providing the highest quality of care by offering patients and their families a complete experience. Most of the target patients are those that might have considered flying to another country for treatment. Interviews with staff and management indicate that the SGMC views its main social impact as its contribution to cancer treatment within the health care ecosystem. In particular, by raising the calibre of health professionals in Ghana, particularly for cancer care, it is anticipated that this will contribute to higher standards within the broader health system, and eventually other competitors and enterprises in the supply chain will emerge over the coming decades. Indeed, SGMC's service offering has already been extended through a series of corporate accounts, where the employer and employees donate into a common fund, giving all employees, their spouses and families access to treatment (not just senior management). Three corporate accounts have been set up so far: the Ghana National Association of Teachers (GNAT), the Electricity Company of Ghana (ECG) and the National Association of Graduate Teachers (NAGRAT). As such, SGMC sees itself as 'helping to lead the way and drive up the standards of public healthcare'. This includes such things as the SGMC team working with Korle Bu Teaching Hospital in Accra, training them to use the linear accelerator equipment ${ }^{18}$.

In addition to SGMC, there were other SMEs of the Trust Fund that seemed to be market makers in their respective sectors, often gaining first-mover advantage. For instance, Scientellect was one of the first DNA testing clinics in Ghana (applying its expertise to everything from family disputes to solving crimes). African University College of Communications was the first non-state funded college on journalism. Caltech Ventures Ltd was the only ethanol producing factory in Ghana.

By considering the portfolio in this way, it is possible to be more precise about likely social impacts and the different pathways to achieving change. While we found this threeclassification typology to be a useful device for this study and its limited sample, it also highlighted how the number of direct jobs created were found, across the three types, to be 18.This is a device most commonly used for external beam radiation treatments for patients with cancer. 
relatively minor contributions to social impact. For the 'job creator' category, the indirect jobs created within the supply chain ranged from hundreds to many thousand times larger than the number of full-time employees. For the 'service providers', it was their very service that contributed to the greatest social effect (improving people's education, health, etc.). And for 'market makers', the change is longer term and systemic in leading the way for subsequent crowding-in. Thus, all three SME types demonstrate interesting, yet different, measurement challenges.

We argue that using this approach to 'pathway segmentation' helps avoid counting the wrong metric. Indeed, the average number of direct jobs (total permanent employment) in our sampled companies is 57 employees per firm - seemingly a relatively low return given the size of investment. ${ }^{19}$ Reporting this figure alone significantly underestimates the wealth of the diverse social impacts within the VCTF portfolio. In addition, 'pathway segmentation' helps untangle distinctly different time horizons for social impact, which are best measured and reported in different ways.

\section{Undervaluing rural businesses (indirect jobs)}

A second lesson from the study is that rural businesses, not typically favoured by venture capitalists, can be effective job creators and, through that pathway, significant social impact generators. This is consistent with the literature, where growth in investing in agriculture is two to four times more effective in reducing poverty than growth in other sectors (AfDB 2013; CAFOD 2011). In Ghana, as elsewhere in sub-Saharan Africa, the rural areas of Ghana are primarily involved in the production of food, for either export or local consumption, and define the main geographies relevant to SDG 2 to 'End hunger and achieve food security and improved nutrition'. Venture capitalists tend to steer away from rural businesses, often concerned about perceived risks and higher operational costs, and generally preferring to invest in companies closer to their offices that they can visit and monitor directly. ${ }^{20}$ While these preferences are wellexplored in the international literature on investing (Chniguir, Kefi \& Henchiri 2018; Cooper \& Kaplanis 1994), only limited research has been conducted on intra-country home bias, such as Coval and Moskowitz (1999). Among the sample of investments in this study, the highest performing companies in terms of impact across a range of social dimensions were found to be the two firms based in the more rural regions: Wenchi Rural Bank and Caltech Ventures Ltd. Importantly, their intent to create pathways for indirect job creation was critical to their success, particularly by using out-grower models and innovations in the supply chain.

For Wenchi Rural Bank, the effect seems to be achieved through its success in providing previously unavailable

19.This is not even just those jobs necessarily attributable to the investment, which would be lower.

20.This is an observation, although there is emerging evidence that in developing countries that there is a 'big-city bias', but that this bias tends to decline as a country develops (Lee \& Luca 2018). financing for the local area, including loans to female-run businesses and to relatively poor borrowers. The SME has a fairly clear articulation of the chain from the rural bank to social impact. For instance, in microfinance, where the enterprise started with 1000 individuals for microloans, this grew to 3500 borrowers by 2016 . With a planned merger, the enterprise is aiming for 20000 microfinance customers by 2020. Particular attention is paid by Wenchi to loans for women. In addition, for Wenchi's susu agents, ${ }^{21}$ one of the criteria of the loans is that if the borrower has children of school age, the children must attend school. Wenchi also engages with local communities, including distributing 10000 exercise books for schools, a long-standing relationship with Wenchi Methodist Hospital (e.g. sponsoring the children's ward) and spreading ownership in the Bank throughout the community (individuals can buy shares for as little as one Ghanaian cedi).

Caltech Ventures Ltd, based in the Volta region, was established as the only homegrown producer of ethanol in the country with the aim of reducing Ghanaian imports of the material. In 2014, the Gold Venture Capital Trust Fund (with financing from VCTF) exited from an equity stake, and now Kasapreko holds an equity stake in the business. ${ }^{22}$ Caltech's factory is based in a remote rural area and produces ethyl alcohol from cassava, as well as $\mathrm{CO}_{2}$, biogas (with the waste being used to generate electricity) and cassava flour. There are 70 permanent employees (mostly in the factory), with around 250 seasonal workers (who work on the plantations doing planting, weeding and harvesting as well as peeling cassava, plus some casual workers in the factory).

While Caltech has its own land on which to grow cassava, the company has also sought to proactively enhance the local supply chain by developing the out-grower network, adding value at the community level and seeking to test a block farming' model that gives opportunities to people with limited land access. Caltech has supported the establishment of out-grower associations, with 220 members, providing early years support, including technical advice and inputs. The firm now has plans to provide added value at the community level, by setting up 10 drying centres based in these communities, each of which will serve 20 farmers allowing them to dry and process cassava.

The business decision to locate in such a remote location (especially in light of transport costs for equipment, parts, sales, etc.) has both advantages and disadvantages. On balance, the founder views that these pros and cons balance out, but that the social impact is much greater by operating in such a location. In fact, a single person who is employed in a

21.A traditional form of financial intermediary.

22.Kasapreko is a Ghanaian beverage enterprise. Its stake in Caltech is part of its import substitution strategy. Kasapreko imports some 25 million litres of ethanol 列 'Company secures deal to produce enth 'Company secures deal to produce ethanol' in Graphic Online, May 2014. http:// www.graphic.com.gh/news/general-news/company-secures-deal-to-produceethanol.html 
business in a remote rural area can have a significant impact on the quality of life of their household and its extended family members, alongside more indirect benefits to community members through seasonal work, vendors and artisans (welders, electricians, etc.). For example, ${ }^{23}$ Beatrice (a seasonal female employee) has worked at Caltech Ventures for 10 years in various capacities including planting, harvesting, processing and now flour production. In an interview, she talked about the work as being life-changing for her, with the key change being in her ability to now support her children at school (paying school fees), improving her house (as it now has several bedrooms) and buying other consumables (such as her collection of shoes). As well as her seasonal employment, she does some farming on her own smallholding. Similarly, Emmanuel (a supervisor and fulltime employee) also observed how employment at Caltech has had a profound effect on his life. He has been at Caltech for 10 years as well, undertaking a variety of supervisory positions (in the field, flour production, machinery, etc.). He talked to us about how the job has helped him greatly: it has been his only source of income and now he doesn't farm. The savings have been invested in two apartments which he rents out, and he plans to do more building work. It has also helped with the education of his three children (paying for school fees). Plus, he sees other benefits. These include being promoted to flour production, and, through in-service training, he has acquired the skills to operate most of the enterprise's machinery. Indeed, the training of staff has been a major benefit for all staff (driving tractors, graders, operating factory machines, etc.). While he indicated that the work is tough, he also noted that there are opportunities to improve oneself and be promoted.

Two of the northern enterprises in our sample (to which the VCTF provided loans 10 years ago) also illustrate the jobcreation capacity of rural SMEs. A limited liability company, the Savannah Farmer Marketing Company (SFMC) provides input and credit to farmer-based organisations (FBOs) and also buys and markets their produce. The SME directly employs 11 permanent staff (including six male and five female employees), which constitutes a relatively small team to run its core operations. SFMC nevertheless indirectly employs some 50 aggregators ${ }^{24}$ - both male and female sole proprietors - who buy the produce of FBOs and sell it to the SFMC. In turn, SFMC sells this produce to regional and national off-takers (e.g. Ghana Nuts, Vestor Oil and the Yedent Agro Processing Company). In addition, the company finances approximately 100 commissioned agents to also buy the crops of FBOs and convey these outputs to SFMC. Altogether, the enterprise works with 330 FBOs that serve an estimated 15000 farm families, half of whose members are women - a considerable indirect job creation compared to just 11 full-time staff. Plus, the enterprise employs between 60 and 150 casual workers each year to

23.The names in the following section have been changed to protect the anonymity of interviewees.

24.Aggregators are intermediary actors in the value chain between the supplier and purchaser. They reduce the transaction costs of individual smallholder engagement by collecting crops from large numbers of small-scale farmers. undertake various harvesting and post-harvest activities, such as winnowing, shelling and sorting crops. They are paid 12 Ghana cedis for winnowing, shelling and sorting one bag of cereal or legume crop; this compensation is considerably higher than the Ghana Government's minimum wage of 9 Ghana cedis and 60 pesewas (GHË 9.60) per day. Other causal workers load and off-load farm produce at the various warehouses of SFMC during harvesting season.

Another Trust Fund loan client in the north, the Heritage Seed Company Limited, is a sole proprietorship business that focuses on quality seed production and sale to farmers. This enterprise employs 11 permanent workers (in this case, 10 male employees and one female). It also employs 40 to 50 inputs suppliers and dealers in fertilisers and crop chemicals. Furthermore, the Heritage Seed Company provides support for 300 seed out-growers, about one-quarter of whom are women, as well as hiring 20 to 60 casual labourers each year to carry out harvesting and post-harvest activities, particularly for winnowing, shelling and sorting seasonal cereal and leguminous crops.

These examples illustrate the various ways in which rural businesses can contribute to job creation, both direct and indirect, and better livelihoods. The economic activity generated by the businesses and the income gained by FBOs, individual farmers and other actors in the supply chain enable participating households to, among other things, support the education of their children. To a certain degree, these efforts help reduce food insecurity among the poorest households. The companies also contribute to reductions in post-harvest losses. These and other benefits can be significant factors in the sustainability of rural families and their communities.

The findings of this study underscore the important job-creating capacity of successful rural businesses, especially those that are part of agricultural value chains or businesses providing financing to other rural enterprises and households. Typically, venture capitalists around the world are urban-based and seek investments within an hour's drive of their offices; this is as true in Africa as in Europe or North America. Such city-centric practices embed an urban bias in venture capital portfolios. African governments, however, are aware that much of the poverty in their countries is clustered outside the main cities in rural towns and villages. Among other things, this suggests that governments and development agencies should consider subsidising the additional time and effort venture capital funds must take to engage with rural SMEs. The payoff from such support should be in the form of increased direct and indirect employment opportunities catalysed by growing rural companies.

\section{Intentionality and social impact}

The third and final lesson from this research is that strengthening an enterprise's social impact over time is 
possible but requires intentionality and focus. ${ }^{25}$ A good number of SMEs in the sample were found to be 'service providers' or 'market makers' that serve elite or middle-class customers. In the early years of the Trust Fund, the focus was on identifying SMEs with pathways to sustainable business models rather than to direct social impact on low-income or marginalised groups. Nevertheless, we found several instances of owners of proven, elite-serving businesses to proactively develop ways to better serve lower income groups. We found innovative examples where initiatives involved more than add-on community projects or simplistic notions of corporate social responsibility (i.e. donations to community projects). These examples were more systemic, such as where entrepreneurs adjusted their business model (and its supply chain) for a broader social gain.

For instance, the owners of an elite-serving health clinic or a middle-class pre-school can provide subsidies or scholarships to create access for some lower income patients or children. There are several examples of this, such as the SGMC, which is initiating 'corporate accounts' where staff members of corporations agree to pay in a small monthly amount into a designated, common fund. In return, this provides all employees, their spouses and families access to treatment (and not solely the senior management). This is a replicable business model that enables employees to gain access to subsidised cancer care if required, regardless of their social position. In 2016, three corporate accounts had been set up with the GNAT, the ECG and the NAGRAT. Alongside this, SGMC operates an internal market (cost centre structure) which allows those who can afford the treatment to pay a little more, while those with less means being offered a range of discounts. Given that SGMC is the only cancer treatment centre in Ghana, it will for the time being remain a high-cost, elite service. But the corporate accounts, in particular, represent an attempt to purposively broaden the availability (and social inclusion) of the service by innovating with different business models.

Another example is Caltech Ventures Ltd which is piloting ways to achieve a wider social effect beyond its existing outgrower networks. To achieve this, it is testing a business model to support indirect job creation through 'block farmers'. These are local people (and potentially the landless) that are allocated one or two hectare blocks of land on which to farm. In return for their labour, the block farmers receive inputs, technical assistance and an agreed price and market for the cassava they produce. This has both a business and social benefit: helping the enterprise to ensure continuity of cassava supply while enabling asset-poor households' access to land, know-how and inputs.

While all the investments in this study had a social aim (cancer care, schooling, creating employment in deprived

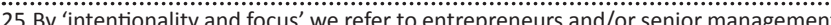
driving forward particular initiatives that are additional to, or alter, the business driving forward particular initiatives that are additional to, or alter, the business model. These were more than simply add-on corporate social responsibility projects (e.g. a donation for a health centre, water pump, etc.) and involved approaches that deliberately attempt to extend services and the supply chain to the benefit of lower income consumers. areas, etc.), the examples above stood out because they were experimenting with innovative ways to further extend services beyond their obvious middle-income or elite client base (or by widening their supply chain to include lower income groups). These initiatives were purposeful attempts by their chief executives to find new business models or alternative ways of subsidising the supply chain for a greater social impact (e.g. cross-subsidising elite services to extend cancer care to others; creating pooled funds or insurance schemes to broaden accessibility; and creating new farming models for the landless). These were not purely motivated by profit but extended social impact where it also made business sense, and each required intentionality and focus on the part of their leadership.

\section{Areas for further research}

In summary, the findings of this study offer practical lessons for investors, enterprises and policy makers. One such lesson is that commonly assumed metrics (like job creation) are not equally applicable to all investments, with some types of SMEs and business models creating social impact in other important ways. We argue for typologies of expected change that take account of very different impact pathways. We go on to suggest three typologies for classifying portfolios by determining whether SMEs are primarily 'job creators', 'service providers' or 'market makers'. Among these typologies, then, we found that the common metric of job creation underplays some important differences. In particular, rural businesses may not always create many direct jobs (and thus effects can be underreported) but can be valuable indirect job creators and, through that pathway, significant social impact generators. Having a mix of different social returns can also contribute to a more balanced portfolio. Indeed, we found that an enterprise's social impact can be further strengthened in time, but this process needs to be managed, requiring intentionality and focus by business leaders.

So, where next for social impact assessment? One of the limitations of this study is that, given time and resource constraints, it was not possible to capture the full diversity of perspectives (from investor and the SMEs receiving the investment, through to employees, consumers and communities). But, as a collaboration between evaluators and venture capitalists, this study does point to a few areas worthy of further enquiry:

Firstly, the study found that to meaningfully capture and achieve social impact requires greater focus on the diversity of impact pathways, plus support for innovation and the purposeful adjustment of business models to reach lower income groups. This requires the sort of support that typically falls under operating costs. As such there is a question of the scale needed to intentionally improve social returns from investments. Venture capital financing is a labourintensive process, particularly if a social (or even environmental) return is expected alongside financial gains. 
For each investment to optimise returns and mitigate risk, investors must take a hands-on, due diligence process at the front-end and through ongoing monitoring and technical advice during the investment period. The VCTF's approach of creating professionally managed sub-funds is a way of dealing with scale to some extent. However, the asset base of the Trust Fund is not yet sufficiently large to significantly increase the number and size of sub-funds and, importantly, the number and size of its investments to achieve the necessary economies of scale. This affects operating costs and the extent to which social impact can be managed, improved, monitored and evaluated. Moving businesses from small to medium size, and from medium to large scale, requires a greater quantum of capital. Addressing the issue of scale thus requires a coalition of interests - from government, finance and business, and development agencies - to join forces. To avoid the question of scale is to avoid the collective responsibility for filling the funding gap of the SDGs.

And secondly, evaluation techniques have a role, but this requires more adaptation to the investment and entrepreneurial context. The experience of this research project suggests that some evaluation techniques can be useful in understanding and improving the social impact of venture investments. For instance, theory of change analysis, a key tool of evaluators, was used to frame, and later reframe, the analysis and provide useful insights; and might be adapted to better understand core assumptions behind the intended social impact as part of a due diligence and reporting requirement. The team also drew on evaluation tools from development finance, such as environmental, social and governance (ESG) indicators. In general, the research team took a collaborative, learning-oriented approach and also maintained its own independent stance. The field of evaluation would appear to have much to offer social impact analysis in venture investing, and this deserves further testing in collaboration with investors and entrepreneurs.

\section{Conclusion}

In conclusion, the international effort to mobilise private and public capital to achieve the SDGs continues. Venture capital investment in SMEs is a crucial element in this agenda. The research reported here highlights the nature and significance of social impacts generated by investments in enterprises, even when there are no explicit social objectives by investors. This research has also shown that the methods and tools of evaluation can play an important role in identifying and assessing the value of such social impacts - and that a typology of impact pathways can usefully highlight the range of impacts typically underrepresented. Together, this underscores the insights that can be gained through collaborative inquiry among investors, investees and evaluation specialists. The process of unlocking more capital to achieve the SDGs can be (in part) fuelled by better knowledge on how mobilised capital leads to development effects - and what additional support is needed, and under which circumstances this can be most effective.

\section{Acknowledgements}

The research was partly funded under the DFID Accountability Grant to the Centre for Development Impact at the Institute of Developments Studies (IDS), from September to December 2016. The authors would like to thank the Venture Capital Trust Fund (Ghana) for supporting the team during field visits and helping to arrange discussions with various investment managers, chief executives and staff. They would also like to thank Hamdiya Ismaila and her staff at the Trust Fund for accommodating them during her busy schedules.

\section{Competing interests}

The authors declare that they have no financial or personal relationships that may have inappropriately influenced them in writing this article.

\section{Authors' contributions}

C.B. led the research and was the lead author of the article. E.J. provided strategic support to the research design and implementation, links to the VCTF in Ghana and substantial contributions and edits to the article. P.O. was the Research Officer undertaking interviews and data collection, plus assistance in writing and editing the article. H.I. provided feedback and support from the VCTF, including insights into the investments and investees for the research. C.A. provided field-level support and conducted interviews for the investments in the north of Ghana.

\section{References}

AfDB, 2013, Supporting the transformation of the private sector in Africa. Private sector development strategy, 2013-2017, African Development Bank, Tunis, viewed 12 March 2016, from http://www.afdb.org/fileadmin/uploads/afdb/ Documents/Policy-Documents/2013-2017_-_Private_Sector_Development_ Strategy.pdf

Barnett, C., O'Flynn, P., Ismaila, H., Agyeyomah, C. \& Jackson, E., 2016, Understanding and optimizing the social impact of venture capital: Three lessons from Ghana, Draft Manuscript, unpublished, Centre for Development Impact, Institute of Development Studies, Brighton.

Catholic Agency For Overseas Development (CAFOD), 2011, Thinking small: Why poor producers and small business owners may hold the key to a sustainable recovery, Policy Discussion Paper, CAFOD, London, viewed 19 March 2016, from http:// cafod.org.uk/content/download/12680/98361/version/4/file/Thinking\%20 Small\%201.pdf

Chniguir, M., Kefi, M. \& Henchiri, J., 2018, 'The determinants of home bias in stock portfolio: An emerging and developed markets study', International Journal of Economics and Financial Issues 7, 182-191.

Cooper, I. \& Kaplanis, E., 1994, 'Home bias in equity portfolios, inflation hedging, and international capital market equilibrium', The Review of Financial Studies $7(1)$ 45-60. https://doi.org/10.1093/rfs/7.1.45

Coval, J.D. \& Moskowitz, T.J., 1999, 'Home bias at home: Local equity preference in domestic portfolios', The Journal of Finance 54(6), 2045-2073. https://doi. org/10.1111/0022-1082.00181

Flynn, J., Young, J. \& Barnett, C., 2015, Impact investments: A literature review, Centre for Development Impact (CDI) Paper, Institute of Development Studies, Brighton.

Flynn, J. \& Young, J., 2016, Annotated bibliography - Evaluating impact investing, IDS Evidence Report 164, Institute of Development Studies, Brighton.

Government of Ghana (GOG), 2004, The venture capital trust fund act (Act 680), Government of Ghana, Accra, Ghana, viewed n.d., from http://laws.ghanalegal. com/acts/id/223/venture-capital-trust-fund-act

IFC \& McKinsey, 2010, Two trillion and counting; Assessing the for micro, small, and medium size enterprises in the developing world, IFC, The World Bank Group, Washington, DC

Jackson, E.T., 2013, 'Interrogating the theory of change: Evaluating impact investing where it matters most', Journal of Sustainable Finance and Investment 3(2), 95-110. https://doi.org/10.1080/20430795.2013.776257 
Jackson, E.T. and Harji, K., 2016, Module 22 - Household Impacts, from the Syllabus for Executive Course - Evaluating Impact Investing in Africa, E.T. Jackson and Associates Ltd, Ontario, Canada.

Jackson, E.T. \& Harji, K., 2017, 'Impact investing: Measuring household results in rura West Africa', ACRN, Oxford Journal of Finance and Risk Perspectives 6(4), 53-66.

Lee, N. \& Luca, D., 2018, The big-city bias in access to finance: Evidence from firm perceptions in almost 100 countries, working papers in responsible banking and finance, University of St. Andrews School of Management, viewed n.d., from https://www.researchgate.net/publication/321775051_The_big-city_bias in access_to_finance_Evidence_from_firm_perceptions_in_almost_100_countries

Lindenberg, N. \& Pöll, C., 2015, Financing global development: Is impact investing an investment model with potential or just blowing smoke?, Briefing Paper 20 German Development Institute, Bonn, Germany.

MacGillivray, A., Kim, R., van Moorsel, T. and \& Kehoe, A., 2017, Measuring total employment effects: A lean data methodology for a portfolio of investments in developing countries, February 2017, CDC Group, London.
Mensah, S., 2004, 'A review of SME financing schemes in Ghana', presented at the UNIDO regional workshop of financing small and medium scale enterprises, Accra, Ghana, 15-16 March 2004, viewed n.d., from http://semcapitalgh.com/ downloads/research/SME_Financing_Schemes_in_Ghana.pdf

So, I. \& Staskevicius, A., 2015, Measuring the 'impact' in impact investing, Harvard Business School, viewed n.d., from https://www.hbs.edu/socialenterprise/ Documents/MeasuringImpact.pdf

United Nations (UN), 2015, Transforming our world: The 2030 agenda for sustainable development, Resolution adopted by the General Assembly on 25 September 2015, United Nations, New York.

UNCTAD, 2017, World investment report 2017-Investment and the digital economy viewed 08 October 2018, from http://unctad.org/en/PublicationsLibrary/wir 2017_en.pdf

UN PRI, 2017, The SDG investment case, Principles for Responsible Investment (PRI), UNEP finance initiative and UN global compact, viewed 08 October 2018, from https://www.unpri.org/pri/what-are-the-principles-for-responsible-investment 